\title{
Współczesne prawosławne prawo kościelne - problemy związane z systematyzacją i materiałami źródłowymi w języku polskim*
}

\author{
ks. Marek Lawreszuk \\ Uniwersytet w Białymstoku, Katedra Teologii Prawosławnej, Polska \\ ORCID: 0000-0001-8051-8106 \\ m.lawreszuk@uwb.edu.pl \\ ks. Piotr Makal \\ Stowarzyszenie Bractwo Prawosławne Świętych Cyryla i Metodego, Polska \\ ORCID: 0000-0003-3854-5076 \\ makal.piotr@gmail.com
}

\begin{abstract}
Ławreszuk M., Makal P., Contemporary Orthodox Church law - problems related to systematization and source materials in Polish language, Elpis, 23 2021: 127-135.

Abstract: The article shows the problems related to the attempt to systematize the modern Orthodox Church law. It points to discrepancies related to the source corpus adopted in individual local Churches, as well as shortcomings or understatements in canon law. The final part of the article touches upon the issue of assessing the complementarity of the source materials in Polish, as well as the difficulties associated with the lack of a systematized terminology of Orthodox church law in Polish.

Streszczenie: Niniejszy artykuł ukazuje problemy związane z próbą systematyzacji współczesnego prawosławnego prawa kościelnego. Wskazuje na rozbieżności związane z przyjętymi w poszczególnych Cerkwiach lokalnych korpusach źródłowych, a także braki lub przemilczenia istniejące w prawie kanonicznym. W części końcowej poruszono także kwestię oceny komplementarności materiałów źródłowych w języku polskim oraz trudności związane z brakiem usystematyzowanej terminologii prawosławnego prawa kościelnego w języku polskim.
\end{abstract}

Keywords: church law, Orthodoxy, canon law, Orthodox Church

Słowa kluczowe: prawo kościelne, prawosławie, prawo kanoniczne, Kościół prawosławny

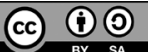

Rzymskokatolickie i prawosławne kodyfikacje prawa kościelnego, już przy pobieżnej analizie wykazują zasadnicze różnice komplementarności. Kodeks Prawa Kanonicznego Kościoła rzymskokatolickiego stanowi spójny, zasadniczo zwięzły i regularnie aktualizowany wykaz obowiązujących norm. W przypadku Kościoła prawosławnego już na wstępie pojawia się problem z jednolitym i precyzyjnym wskazaniem na istnienie podobnego kodeksu (Przekop, 1977, s. 173).

Prawosławne prawo kościelne składa się z elementów, które regulują życie cerkiewne na różnych poziomach. Teologiczne postanowienia, orosy, kanony i listy kanoniczne, które dotyczą Cerkwi globalnie, koncentrują się, co oczywiste na doktrynie, jak również charakteryzują teologiczne aspekty eklezjologii wyrażane przede wszystkim w fundamentalnym dla Cerkwi prawosławnej Nicejsko -konstantynopolitańskim wyznaniu wiary. Szereg kano-

\footnotetext{
* Publikacja finansowana w ramach programu Ministra Nauki i Szkolnictwa Wyższego pod nazwą „Narodowy Program Rozwoju Humanistyki” w latach 2017-2022, nr projektu 0083/NPRH5/H11/84/2017.
}

nów soborów powszechnych, świętych Ojców, historyczne i współczesne postanowienia soborów Cerkwi lokalnych i innych władz oraz instytucji cerkiewnych również, w pewnych aspektach, dotyka przestrzeni powszechnej, chociaż w znakomitej większości wyznacza pewne normy organizacji życia cerkiewnego w perspektywie lokalnej: lokalnej Cerkwi, podstawowej jednostki administracyjnej (diecezji, metropolii lub egzarchatu), a przede wszystkim w podstawowych strukturach organizacyjnych: parafiach i monasterach.

Współczesna analiza prawosławnego prawa kościelnego w naturalny sposób porównuje je z rzymskokatolickim prawem kościelnym, jak również z innymi, niezależnymi gałęziami prawa (Znosko, 1973, s. 19). Ponieważ prawo to nie istnieje $\mathrm{w}$ izolacji, musi mieć powiązania $\mathrm{z}$ innymi naukami prawniczymi, które dostarczyły mu i dostarczają podstawowych pojęć prawniczych oraz materiału do jego struktury. Źródłem pojęć jest głównie prawo rzymskie i filozofia, a materiał struktury prawa kościelnego został zaczerpnięty z kultury helleńskiej, judaistycznej oraz cywilizacji rzymskiej i bizantyjskiej (Znosko, 1973, s. 19). 
Oparta na teorii prawa struktura prawosławnego prawa kościelnego jest niekompletna. Niektóre z gałęzi są rozwinięte i szczegółowe, inne zaś wydają się potraktowane zdawkowo. Nie stanowi to w żadnym wypadku powodu do krytyki jakości tego prawa, gdyż kościelny system prawny nigdy nie rozwijał się z mocy jednorazowej i świadomej decyzji prawodawcy, lecz był rezultatem historycznego procesu. Ponieważ jednak prawo powinno dotyczyć wszystkich przejawów życia społeczności objętej danym prawem, a nawet sięgać dalej i odpowiadać na kwestie dotyczące relacji określonej społeczności ze światem niepodlegającym zasadom tego prawa, podejmując się systematyki tego prawa, należy jednoznacznie określić, czy prawo to dotyczy wszystkich tych elementów?

\section{Model systematyzacji prawosławnego prawa kościelnego}

Próba systematyzacji prawa kościelnego musi pokonać problem braku globalnego ujęcia Cerkwi w normach prawnych. Charakterystyka Cerkwi postrzegana przez pryzmat kanonów, tj. przepisów prawnych, odnosi się do Cerkwi lokalnej i wszystkich elementów jej życia. Pomija przy tym istotny eklezjalny element wzajemnych relacji wszystkich Cerkwi lokalnych. Badacze prawa kościelnego próbują wypełniać lukę systematyzacji, wprowadzając autorskie systemy opisywania realności tego prawa. Omawiana w podręcznikach struktura dotyka, ich zdaniem, wszystkich aspektów życia cerkiewnego. W modelu polskiego teologa i znawcy prawa kościelnego ks. A. Znosko odnajdziemy strukturę prawa kościelnego, która dotyczy kolejno:

- terytorium objętego regulacją prawa kościelnego, tj. wskazania poszczególnych elementów Cerkwi, wspólnoty cerkiewnej, czyli duchowieństwa, laikatu, mnichów, władzy cerkiewnej oraz terenu;

- organizacji Cerkwi, tj. struktury globalnej i lokalnej;

- władzy cerkiewnej;

- relacji Cerkwi z innymi strukturami, m.in. państwem, związkami religijnymi i społecznościami nieprawosławnymi (Znosko, 1973, s. 23-24).

Inne modele możemy znaleźć w dziełach światowej sławy kanonistów, m.in.: G. Ralliego, M. Potliego (Rallis i Potlis, brak daty), A. Pawłowa (Pavlov, 1902), W. Beneszewicza (Beneševič, 1914), biskupa Nikodema Milasza (Nikodim episkop Dalmatinskij, 1897), archim. Eufemiusza Jovanovicia (J̌ovanović, 1844). Analiza ich opracowań nie rozwieje jednak wszystkich wątpliwości związanych z próbą systematycznego przedstawienia przedmiotu naszej analizy.

\section{Terytorium i zasięg prawa}

Pewne problemy rodzą się $\mathrm{w}$ aspekcie określenia obszaru objętego regulacją prawa kościelnego. Podstawowa charakterystyka nie stanowi źródła rozbieżności. Prawo sprawowania władzy Cerkwi ma charakter powszechny, tj. obejmuje cały świat. Władza ta ma dodatkowo charakter duchowy i dobrowolny (Znosko, 1973, s. 142). Do dzisiaj nie zostały ujednolicone kwestie terenu objętego przepisami prawnymi określonego stopnia. O ile obszar objęty powszechnym prawosławnym prawem kościelnym jest rozumiany jednoznacznie, to problem tkwi w jednoznacznym określeniu granic obowiązywania prawa lokalnego, dotyczącego konkretnej Cerkwi lokalnej lub terenu dotychczas nieobjętego zasadami prawa kościelnego. Brak jednoznacznej interpretacji istniejących norm prawnych oraz próby interpolacji zasad prawnych z różnych lokalnych wspólnot na tereny dotychczas nieobjęte tymi zasadami rodzą problemy $\mathrm{w}$ tworzeniu szczegółowych przepisów dotyczących m.in. pewnych odstępstw od zasad terytorialnych w Cerkwi, tj. organizacji życia diaspor, tworzenia metochionów czy ustanawiania stauropigii lub egzarchatów (Znosko, 1973, s. 143-147).

Powiązanym ze wskazanym wyżej obszarem prawnym, który również może sprawiać problem w momencie precyzyjnej identyfikacji, jest określenie zasięgu terytorialnej władzy cerkiewnej. Granice terenów organizacji cerkiewnych ulegały i mogą ulegać zmianom. Zasadniczo istnieją dwie drogi wprowadzania zmian. Pierwsza z nich to sposób pierwotny, który jest określany również jako oryginalny. To zmiana granic terytorialnych jednostki cerkiewnej następująca w wyniku działalności misyjnej (Znosko, 1973, s. 148). Druga droga to zmiana jurysdykcji nad terenem przynależnym określonej Cerkwi lokalnej i przekazanie go w jurysdykcję innej Cerkwi lokalnej. Ten ostatni sposób zmiany zasięgu terytorialnego władzy cerkiewnej, określany jako sposób derywatywny lub pochodny, może przyjmować różne formy: przekazania władzy innej Cerkwi lokalnej, wyodrębnienia struktur autonomicznych lub wyodrębnienia struktur autokefalicznych (Znosko, 1973, s. 150). Szereg zasad dotyczących zmian zasięgu terytorialnego został opisany w przepisach prawa kanonicznego. Mają one charakter prawa szczegółowego, partykularnego, dotyczącego często określonych historycznych wydarzeń, chociaż nie brakuje wśród nich i takich, które omawiają uniwersalne mechanizmy. Przykładem takiej normy prawnej jest wskazanie 30 lat jako okresu, po którym władza cerkiewna na określonym terenie przyjmuje statut „nietykalności”. Zasada ta została przedstawiona w 17 kanonie IV Soboru Powszechnego (Znosko, 1973, s. 151). Normy prawne dotyczące zasięgu terytorialnego, przez swoje rozproszenie w korpusie postanowień kanonicznych nie ułatwiają jednoznacznego uporządkowania i, jak wskazują na to współczesne interpretacje kanonistów z różnych Cerkwi lokalnych, dają pole do wysnucia całkowicie odmiennych wniosków, co staje się szczególnie niebezpieczne w sytuacjach sporów terytorialnych.

\section{Organizacja Cerkwi}

Kolejny element prawosławnego prawa kościelnego wydaje się być zbudowany na solidnym fundamencie prawosławnej eklezjologii, postanowieniach soborowych 
i licznych dziełach patrystycznych. Dotyczy on charakterystyki tego, czym jest Cerkiew, jakie są jej składowe elementy, jakie cechy, przymioty stanowią stały element podstawowej nauki o Cerkwi. Jednak zbyt często, w oparciu o naukę dogmatyczną zawartą w Nicejsko-konstantynopolitańskim symbolu wiary, organizacja Cerkwi jest omawiana wyłącznie na przykładzie wzorcowych „,eech” zapisanych w tym symbolu, tj. jedności, świętości, soborowości i apostolskości. Są one swoistą preambułą opisująca to, w jaki sposób Cerkiew jest postrzegana przez Boga, oraz powinna być postrzegana przez otaczający świat i wiernych do niej należących. W takim ujęciu zanika całkowicie wskazanie na normy prawne, które wspierają i chronią Cerkiew przed naruszeniem którejś z jej dogmatycznych cech i przez to przed wypaczeniem postrzegania jej funkcji w świecie.

Doskonałym przykładem tej metodologii jest dookreślenie jednej z cech Cerkwi, a mianowicie powszechności. W traktatach eklezjalnych jest ona wyjaśniana jako cecha „nieograniczoności określoną przestrzenią, lecz obejmującą cały kosmos (rozumiany tutaj jako wszechświat - MŁ)" (Znosko, 1973, s. 156). Powyższa charakterystyka jest całkowicie słuszna i poprawnie skonstruowana w kontekście nauczania o Cerkwi, natomiast w żadnym stopniu nie odpowiada potrzebom określenia mechanizmów wspomagających realizację takiego założenia w ziemskich realiach. W oparciu o powyższy przykład możemy stwierdzić, że problemem prawosławnego prawa kościelnego jest brak przepisów ogólnych, które „nauczanie” o Cerkwi przekładałyby w „prawo” regulujące życie Cerkwi. Po raz kolejny możemy zauważyć, że zbiory kanoniczne wskazują na liczne normy szczegółowe, często uwarunkowane geograficznie lub historycznie. Trudnym zadaniem staje się już jednak odnalezienie jednoznacznych i prostych norm.

Analiza opisów organizacji Cerkwi pozwala zauważyć, że wykorzystuje się w tym celu rozmaite mechanizmy. Niekiedy charakterystyka koncentruje się na znaczeniu dogmatycznym, bądź modelu eklezjalno-dogmatycznym. Struktura charakteryzowana jest jako „Bogoludzki organizm" łączący przestrzenie horyzontalne (wierni) i wertykalne (świat widzialny z niewidzialnym), jako „mistyczne ciało Chrystusa". W innym modelu organizacja ukazywana jest jako struktura hierarchiczna oparta na wzorcu zstępującym: Chrystus, hierarchia cerkiewna, wierni lub wstępującym: wierny, duszpasterz, Chrystus. Jeszcze inny model wskazuje na organizację Cerkwi lokalnej: zwierzchnik, duchowieństwo, laikat, lub wreszcie na model powszechnej Cerkwi, która składa się z wielu Cerkwi lokalnych.

Szczególnie w przypadku operowania ostatnim ze wskazanych modeli, dużym problemem staje się odnalezienie i wskazanie norm prawa kościelnego regulujących wzajemne relacje Cerkwi lokalnych i organizację ich życia na poziomie wzajemnych relacji oraz reprezentowania Cerkwi w świecie zewnętrznym.

Zdaniem A. Znosko integralność Cerkwi powszechnej charakteryzują określone zasady prawne (Znosko, 1973, s. 177). Niestety są one rozproszone w postanowieniach soborów powszechnych, soborów lokalnych i komentarzach kanonistów, przez co nie tworzą zwartego i ujednoliconego materiału.

Integralność wyraża się w następujących zasadach:

- Postanowienia dogmatyczne są definiowane na poziomie powszechnym. Cerkiew lokalna nie ma samodzielności w dziedzinie nauki dogmatycznej.

- Powszechne obowiązywanie nauki kanonicznej.

- Zróżnicowanie liturgiczne nie może naruszać jedności dogmatycznej.

- Każda z Cerkwi lokalnych jest pełnoprawnym i równouprawnionym elementem Cerkwi powszechnej. Honorowa i historyczna kolejność umieszczana w dyptychach nie ma wpływu na to równouprawnienie (Znosko, 1973, s. 179).

Każdy ze wskazanych modeli organizacji Cerkwi funkcjonuje $\mathrm{w}$ pełni legalnie $\mathrm{i} \mathrm{w}$ zgodzie $\mathrm{z}$ nauczaniem eklezjalnym Cerkwi prawosławnej. Mają jednak one charakter deklaratywno-opisowy, wskazując na cechy, przymioty, właściwe relacje, bez wskazania odpowiednich narzędzi i prawnych mechanizmów, które mogą dany model ocalić.

\section{Wladza cerkiewna}

Hierarchiczny charakter organizacji cerkiewnej opisany w prawie kościelnym ma swoje słabości. Wśród nich nadrzędną wydaje się koncentracja na zachowaniu porządku i organizacji życia laikatu, duchowieństwa i hierarchii. Kolejnym objętym normami prawnymi wątkiem jest charakterystyka Cerkwi lokalnej. Najbardziej pomijanym elementem jest jednak określenie wzajemnych relacji, praw, obowiązków i kierunku działań podejmowanych przez zdecentralizowaną władzę Cerkwi lokalnych, tj. zobowiązań zwierzchników bądź soborów lokalnych do wspólnych działań.

W podobny sposób możemy scharakteryzować instytucje sądowe i odwoławcze Cerkwi prawosławnej. Są one skoncentrowane na podejmowaniu działań wobec laikatu i duchowieństwa na szczeblu diecezjalnym, lokalnym, a nawet powszechnym. Nie podejmują jednak kwestii organów władzy kościelnej, kontroli ich prerogatyw, czy sposobów uzdrawiania sporów i konfliktów na szczeblu powszechnym.

\section{Relacje Cerkwi z innymi strukturami}

Bilateralne komisje teologiczne z innymi Kościołami, państwowo-cerkiewne komisje majątkowe, prawodawstwo świeckie, a od niedawna prawodawstwo unijne i zasady organizacji międzynarodowych, z którymi Cerkiew wchodzi w relacje - wszystkie te sfery powinny opierać się po stronie cerkiewnej na normach prawa kościelnego. Wnioski, wypracowane stanowiska czy przyjęte w efekcie dialogu decyzje wraz z dokumentacją stają się już jednak nowymi elementami wpływającymi lub zmieniającymi po- 
szczególne przepisy prawne. Aktywna działalność Cerkwi na arenie międzynarodowej, żywy dialog ekumeniczny oraz nieustannie zmieniające się prawodawstwo świeckie prowadzą do konieczności aktualizacji przepisów prawa kościelnego uwzględniającego nowe uwarunkowania.

W szczególnych sytuacjach pojawia się pytanie o prerogatywy podejmowania decyzji „, imieniu” Cerkwi prawosławnej, reprezentowania całości Cerkwi powszechnej, bądź ustalania kwestii wykraczających poza kompetencje Cerkwi lokalnej.

\section{Trudności systematyzacji i zagrożenia $z$ niej wynikające}

Krytyczna analiza prawosławnego prawa kościelnego rodzi niebezpieczeństwo wyciągnięcia błędnych wniosków. Wskazane wyżej braki nie stanowią punktu wyjścia do odrzucenia dotychczasowego modelu i wprowadzenia rewolucyjnych zmian. Brak w pełni opisanych klauzul prawnych dotyczących wszystkich elementów życia Cerkwi wynika z przyjętej w prawosławiu drogi podejmowania decyzji. Mechanizm budujący tę drogę został wdrożony $\mathrm{w}$ epoce soborów powszechnych. To mechanizm reagowania. Wszystkie dogmatyczne orosy wyjaśniające nauczanie Cerkwi o Bogu, dziele zbawienia, czy relacji Boga z człowiekiem, pojawiały się jako reakcja na błędną naukę i dążenie do ocalenia jedności Cerkwi. Nie były wynikiem teoretycznych rozważań, tworzenia koncepcji teologicznych czy budowaniu spójnego systemu. Rodziły się w wyniku impulsu, który zagrażał ortodoksyjnemu postrzeganiu Boga i prawidłowej z Nim relacji.

Podobnie powinniśmy postrzegać prawosławne prawo kościelne. Nie było ono budowane jako komplementarny system, lecz konstytuowało się jako reakcja na aktualne potrzeby. Dysfunkcja relacji duchowieństwa ze światem zewnętrznym zrodziła kanony dyscyplinarne regulujące te relacje. Problemy moralne wiernych i duchowieństwa prowokowały do określenia prawnych granic i wynikających $\mathrm{z}$ ich przekroczenia kar.

Samoidentyfikacja Cerkwi prawosławnej ma w prawie kościelnym wymiar teologiczny, oparty o dogmatyczną charakterystykę Nicejsko-konstantynopolitańskiego symbolu wiary. Kolejny poziom identyfikacji to poziom administracji wewnętrznej Cerkwi lokalnej. W tym ciągu postanowień i orzeczeń prawnych brakuje charakterystyki struktury administracyjnej Cerkwi powszechnej.

To właśnie decentralizacja struktur cerkiewnych, historycznie związana z utworzeniem pierwszych patriarchatów i później kolejnych Cerkwi lokalnych, doprowadziła do uszczegółowienia postanowień prawa kościelnego na poziomie struktur lokalnych. Podobnie, jak w przypadku postanowień dogmatycznych widzimy tutaj wyłącznie reakcję na zaistniałą historyczną rzeczywistość.

Problemem współczesnego prawosławnego prawa kościelnego jest oparcie się na dwóch filarach: prawie kanonicznym i świadomości prawnej poszczególnych Cerkwi lokalnych (Znosko, 1973, s. 174). Gradacja tych filarów wydaje się oczywista i wskazuje na pierwszeństwo prawa powszechnego ponad prawem lokalnym. W rzeczywistości brak orzeczeń kanonicznych na poziomie powszechnym dopuszcza wykorzystanie przepisów lokalnych, przy czym ignorowany jest niekiedy w takiej sytuacji zasięg obowiązywania określonego przepisu. Lokalne prawo Patriarchatu Aleksandryjskiego, przy braku powszechnie obowiązującej normy prawnej, może być zaadoptowane do prawa innych Cerkwi lokalnych.

\section{Źródla prawa kościelnego}

Próbując usystematyzować prawo kościelne nie będziemy mieli problemu z określeniem jego źródeł, które dzielimy na materialne i formalne. Ich zwięzłej analizy dokonał już ks. A. Znosko wskazując przy tym na ich hierarchię oraz zakres obowiązywania (Znosko, 1973, s. 31-85). Ogólna charakterystyka źródeł materialnych:

\section{- Pismo Święte}

- przedstawiające niezmienne i powszechne zasady i przykazania wyrażające wolę Jezusa Chrystusa (Nikodim episkop Dalmatinskij, 1897, s. 40);

- zawierające szereg innych postanowień apostołów dotyczących prawa kościelnego (Nikodim episkop Dalmatinskij, 1897, s. 40-41);

- poświadczające obowiązywanie poszczególnych zasad i przykazań starotestamentowych (Nikodim episkop Dalmatinskij, 1897, s. 43);

- oparte na woli Bożej i woli Cerkwi (Znosko, 1973, s. 31-33);

- Tradycja Święta

- uznana na równi z autorytetem Pisma Świętego przez apostołów, sobory lokalne i powszechne: m.in. 21 kanon Soboru w Gangrze, 7 kanon VII Soboru Powszechnego, 91 kanon Bazylego Wielkiego (Nikodim episkop Dalmatinskij, 1897, s. 45; Baron i Pietras, 2006, s. 128);

- oparta na woli Bożej i woli Cerkwi (Znosko, 1973, s. 31-33);

- Ustawodawstwo Cerkiewne:

- Sobory powszechne

- stanowiące źródło powszechnego prawa kościelnego;

- Cerkiew uznaje 7 soborów powszechnych i 189 kanonów na nich przyjętych;

- uzupełniające prawo kościelne o: postanowienia dogmatyczne, postanowienia kanoniczne, wyroki sądowe (Znosko, 1973, s. 36-37);

- Sobory lokalne

- Historyczne sobory biskupów lub przedstawicieli niektórych Cerkwi lokalnych;

- Pierwszym takim soborem był sobór apostolski w Jerozolimie w 51 roku;

- Postanowienia 10 soborów lokalnych zostały później przyjęte jako ogólnie obowiązujące; są to sobory w: Ancyrze (314), Neocezarei (314- 
325), Gangrze (340), Antiochii (341), Laodycei (341), Sardyce (343), Konstantynopolu (394), Kartaginie (419), Konstantynopolu (842), Konstantynopolu (879) (Znosko, 1973, s. 37-38);

- Współczesne sobory stanowiące prawo kościelne w Cerkwiach lokalnych;

- Ustawodawstwo biskupów

- Kanony 13 biskupów: 12 zbiorów uznanych w 2 kanonie Soboru in Trullo za powszechnie obowiązujące i 1 zbiór uznany za powszechny zgodnie z postanowieniem VII Soboru Powszechnego (Znosko, 1973, s. 39-40);

- Zbiory kanonów

- Opracowania kanoniczne stanowiące kompilację obowiązujących praw:

- Kanonikon patriarchy konstantynopolitańskiego Jana Postnika stanowiący podstawę Nomokanonu słowiańskiego;

- 49 kanonów patriarchy konstantynopolitańskiego Nicefora Wyznawcy, które weszły częściowo w skład innych zbiorów: Kormczej (23 kanony), Pedalionu (37 kanonów), Syntagmy Ateńskiej (38 kanonów) (Znosko, 1973, s. 41);

- 11 kanonów Mikołaja Gramatyka przedstawionych w: Pedalionie (Agapius a Hieromonk i Nicodemus a Monk, 1957), Syntagmie Ateńskiej (Rallis i Potlis, brak daty) i w Kormczej (Kormčaâ napečatana $\mathrm{s}$ " originala patriarha Iosifa, 1912);

- Kanony Bazylego Wielkiego, Jana Chryzostoma, Atanazego Antiocheńskiego (Znosko, 1973, s. 41);

Ogólna charakterystyka źródeł formalnych:

- Źródła wczesnochrześcijańskie, pisma Mężów Apostolskich i Ojców Apostolskich, najstarsze zabytki piśmiennictwa chrześcijańskiego:

- Pisma Klemensa Rzymskiego, Ignacego Antiocheńskiego, Dionizego Aleksandryjskiego, Grzegorza z Neocezarei, Piotra Aleksandryjskiego, Ireneusza z Lyonu, Cypriana z Kartaginy, Tertuliana;

- Didache, Didaskalia, Kanony Apostolskie zawarte w Konstytucjach Apostolskich

- Źródła epoki soborów powszechnych, zbiory kanoniczne, cywilne i mieszane:

- Zbiory chronologiczne: Zbiór Poncki, Synopsa Stefana z Efezu, Kodeks Afrykański (Znosko, 1973, s. 57-58);

- Zbiory systematyczne: Syntagma 50 tytułów Jana Scholastyka, Syntagma 14 tytułów, które później zostały włączone do nomokanonów (Znosko, 1973, s. 58-59);

- Bizantyjskie zbiory praw cywilnych dotyczących Cerkwi: m.in. Kodeks Teodozjusza, Kodeks Justyniana, Digesta Justyniana, Instytucje Justyniana, Nowele Justyniana, Ekloga Leona V, Procheiron z 879 r., Epanagoga z lat 884-886, Bazyliki. Wszystkie zbiory Justyniana noszą nazwę Corpus iuris civi- lis, które zostały wydane w latach 528-534 (Znosko, 1973, s. 59-60);

- Zbiory mieszane - nomokanony: m.in. Nomokanon 50 tytułów, Nomokanon 14 tytułów, nomokanony pokutne;

- Późniejsze źródła formalne:

- Zbiory Cerkwi lokalnych;

- Autorytatywne interpretacje starożytnych przepisów prawa kościelnego (Aleksego Aristenesa, Jana Zonarasa, Teodora Balsamona, Dymitra Chomatiana);

Materiały źródłowe były gromadzone i publikowane w wielu redakcjach, wśród których największe znaczenie w prawosławnym prawodawstwie kościelnym posiadają: Syntagma Ateńska, alfabetyczna Syntagma Mateusza Blastaresa, zbiór Konstantego Armenopulosa, Pidalion, Nomokanon 14 tytułów, Nomokanon 50 tytułów, Kormcza św. Sawy Serbskiego oraz drukowana Kormcza (Znosko, 1973, s. 71-75).

Współczesne kodeksy prawosławnego prawa kościelnego Cerkwi lokalnych opierają się na greckiej redakcji Pidalionu oraz słowiańskiej drukowanej redakcji księgi Kormczej. Grecki Pidalion został w 1800 roku przetłumaczony przez D. Cummingsa na język angielski i wydany pod tytułem „The Rudder” (Agapius a Hieromonk i Nicodemus a Monk, 1957).

\section{Materiały źródłowe w języku polskim}

Przedstawiony powyżej przegląd źródeł prawosławnego prawa kościelnego obnaża kolejny problem związany z podejmowaniem dalszych badań. Problemem tym jest brak polskich przekładów wyżej wspomnianych tekstów. Z perspektywy analizy historycznej dotkliwy jest brak polskich wydań komentarzy kanonistów, czy też poszczególnych kodeksów. Problem ten dotyka jednak nie tylko historycznych materiałów źródłowych, lecz przede wszystkim współczesnych zasad prawnych. Przepisy prawa kościelnego obowiązujące w Polskim Autokefalicznym Kościele Prawosławnym są przetłumaczone i wydanie jedynie fragmentarycznie. Opublikowane i dostępne są postanowienia soborów powszechnych i 10 soborów lokalnych. Pośród wielu braków najbardziej dotkliwym jest brak aktualnego Kodeksu prawosławnego prawa kościelnego, tj. odpowiednika greckiego Pidalionu czy słowiańskiej Kormczej oraz autorytatywnych komentarzy (np. Jana Zonarasa czy Teodora Balsamona).

Taki stan potwierdzają prace nad terminologią prawosławną $\mathrm{w}$ języku polskim, realizowane $\mathrm{w}$ ramach grantu Narodowego Programu Rozwoju Humanistyki. Zespół badawczy ze wszystkich specyficznych terminów dotyczących prawosławia wyodrębnił 367 haseł opatrzonych specjalistycznym kwalifikatorem „kanoniczny”. Dotyczą one: prawosławnego prawa kościelnego i kanonicznego, struktury administracyjnej, osób prawnych i stanowisk cerkiewnych (Czarnecka, Ławreszuk i Przyczyna, 2018, s. 225-226). Opierając się na strukturze bazy wszystkich 
terminów liczącej ponad 4000 terminów, wyodrębnionych z materiałów źródłowych, należy wskazać, że terminy specjalistyczne dotyczące prawosławnego prawa kościelnego stanowią $9,1 \%$ całości. Porównanie $\mathrm{z}$ terminami opisanymi innymi kwalifikatorami specjalistycznymi wygląda następująco: terminy teologiczne i biblistyczne obejmują $17,8 \%$, natomiast terminy związane $\mathrm{z}$ prawosławną obrzędowością i sztuką cerkiewną obejmują 23,1\% ogółu artykułów hasłowych. Biorąc pod uwagę, że kwalifikator „kanoniczny” obejmuje ustalenia regulujące wszystkie aspekty życia Cerkwi, jej organizację, strukturę (w tym osoby prawne i stanowiska cerkiewne), zarządzanie, prawa, obowiązki, nagrody i kary kanoniczne, oczekiwany był znacznie wyższy wynik.

Ponieważ badania dotyczyły terminów istniejących w polskiej terminologii prawosławnej wyekscerpowanych ze współczesnych polskojęzycznych źródeł, wynik sprowokował do analizy materiałów źródłowych.

Zespół badawczy mianem polskiej terminologii prawosławnej określił zbiór terminów: „związanych z religijnością i duchowością Cerkwi prawosławnej; obejmujących wybraną terminologię chrześcijańską pierwszego tysiąclecia; z zakresu trzech wyodrębnionych aspektów prawosławnego życia religijnego: doktryny (nauczania), prawa i praktyki” (Charkiewicz, 2018, s. 182). Terminologia prawa kościelnego została już na wstępie określona jako jeden z trzech głównych elementów całości. Baza źródłowa objęła źródła wyspecjalizowane i niewyspecjalizowane. W tej ostatniej grupie znalazło się sześć źródeł słownikowych i leksykograficznych, w tym współczesna pozycja specjalistyczna opracowana w 2016 roku przez zespół naukowy zorganizowany przy Katedrze Teologii Prawosławnej Uniwersytetu w Białymstoku „Specyfika polskiej terminologii prawosławnej. Koncepcja normalizacji pisowni" (Charkiewicz, 2018, s. 182-183). Uzupełnieniem bazy źródłowej stało się 27 źródeł wyspecjalizowanych, zgrupowanych tematycznie w 3 działy: doktryna -9 pozycji, prawo -7 pozycji oraz praktyka - 11 pozycji (Charkiewicz, 2018, s. 186). Poszukiwania materiałów źródłowych ukazały na problem związany z brakiem obecności wielu opracowań dotyczących prawosławnego prawa kościelnego w języku polskim.

J. Charkiewicz w swoich badaniach ukazał, że duża liczba źródeł z dziedziny doktryny sprawiła, że zespół badawczy zdecydował o przeniesieniu części z nich do bibliografii i wykorzystywania ich jedynie uzupełniająco (Charkiewicz, 2018, s. 185). Podobny mechanizm miał zastosowanie w przypadku wyodrębnienia haseł z dziedziny praktyki. W przypadku oznaczania źródeł prawnych, poszukiwania i wybór tych materiałów został scharakteryzowany jako „stosunkowo ograniczony w porównaniu z działami doktryna i praktyka" (Charkiewicz, 2018, s. 185), co w efekcie doprowadziło do sytuacji, że do bazy źródeł „Słownika polskiej terminologii prawosławnej” włączono niemal całą polskojęzyczną literaturę z zakresu prawosławnego prawa kościelnego.

Baza źródeł wyspecjalizowanych z dziedziny prawa objęła prace ks. Aleksego Znosko: „Prawosławne prawo kościelne" w 2 tomach opublikowane w Warszawie w latach 1975 i 1975, „Kanony Kościoła Prawosławnego” w 2 tomach oraz zewnętrzne i wewnętrzne dokumenty prawne regulujące działalność Kościoła prawosławnego w Polsce. Korpus źródeł prawnych obejmuje następujące pozycje: A. Znosko, Prawostawne prawo kościelne, cz. 1, Chrześcijańska Akademia Teologiczna w Warszawie, Warszawa 1973; A. Znosko, Prawostawne prawo kościelne. Zagadnienia wybrane, cz. 2, Chrześcijańska Akademia Teologiczna w Warszawie, Warszawa 1975; Kanony Kościoła Prawosławnego, przekł. ks. dr A. Znosko, I i II, Wydawnictwo „Bratczyk”, Hajnówka 2000; Ustawa z dnia 4 lipca 1991 r. o stosunku Państwa do Polskiego Autokefalicznego Kościoła Prawostawnego, Dz. U. z 2014 r. poz. 1726; Statut Wewnętrzny Polskiego Autokefalicznego Kościoła Prawostawnego, [w:] „Wiadomości PAKP” 1999, nr 1, s. 4-7; Statut Parafialny Polskiego Autokefalicznego Kościota Prawosławnego, [w:] „Wiadomości PAKP” 1999, nr 2, s. 4-7; Statut Monasterów Męskich i Żeńskich Świętego Polskiego Autokefalicznego Kościoła Prawosławnego, [w:] „Wiadomości PAKP” 1999, nr 10, s. 4-7.

Spośród pominiętych w bazie źródeł opracowań w języku polskim, możemy wskazać zaledwie kilka prac skoncentrowanych na tematyce prawa kościelnego, przy czym są one najczęściej fragmentarycznym ujęciem tej dziedziny, skoncentrowanym na wybranych zagadnieniach. Często są to opracowania wykraczające poza tematykę prawa kościelnego, uzupełnione o analizy eklezjalne, teologiczne, historyczne lub liturgiczne.

Wśród opublikowanych w języku polskim prac dotyczących tematyki prawosławnego prawa kościelnego możemy wymienić m.in. następujące pozycje ostatnich dekad: Betlejko J., Święty i Wielki Sobór Cerkwi Prawosławnej (Betlejko, 2017), Blaza M., Synodalność (soborowość) w Kościołach wschodnich (Blaza, 2020), Bóg żywy. Katechizm Kościoła Prawosławnego (Bóg żywy. Katechizm Kościoła Prawosławnego, 2001), abp Anastazy Yannoulatos, Misja na wzór Chrystusa (Yannoulatos, 2016), bp Andrzej Borkowski, Ekumenizm a realizacja misyjnego postannictwa Kościoła w kontekśsie dokumentów Wszechprawostawnego Synodu na Krecie (Borkowski, 2019), Charkiewicz J., Kanonizacja świętych w prawosławiu (Charkiewicz, 2014), Dudra S., Polski Autokefaliczny Kościót Prawosławny w obszarze polityki wyznaniowej oraz polityki narodowościowej Polski Ludowej i III Rzeczypospolitej (Dudra, 2019), Hryniewicz W., Zasada ,ekonomii eklezjalnej" $w$ życiu i teologii prawostawia (Hryniewicz, 1981), Kałużny T., Prawosławie i ekumenizm. Kontrowersyjny dokument Soboru na Krecie (2016) (Kałużny, 2019), Kałużny T., Oikonomia kościelna w teorii i praktyce Prawosławia (Kałużny, 2018), Kanony Kościoła prawosławnego w przekładzie ks. A. Znosko (Znosko, 2000), Katechizm Cerkwi Prawostawnej (Katechizm Cerkwi prawostawnej, 2001), abp Jakub Kostiuczuk, Proces formułowania i doprecyzowania spotecznej nauki w oficjalnych dokumentach Rosyjskiego Kościoła Prawosławnego (Kostiuczuk, 2018), Ekumenizm $w$ dobie wspótczesnych wyzwań (Kostiuczuk, 2013), Krukowski J., Prawo administracyjne w Kościele 
(Krukowski, 2011), Kuźma A., Istota eklezjologii pierwszego tysiaclecia $w$ ujęciu prawostawnym i rzymskokatolickim $w$ świetle dokumentu: „Synodalność i prymat $w$ pierwszym Tysiacleciu: Ku wspólnemu rozumieniu w stużbie jedności Kościoła”, Chieti 2016 (Kuźma, 2019), Wielki Sobór Kościoła Prawosławnego na Krecie w 2016 r. i jego ustalenia (Kuźma, 2018), Ławreszuk M., Prawosławie wobec tendencji nacjonalistycznych i etnofiletystycznych (Ławreszuk, 2009), Pojęcie „terenu kanonicznego" we wspótczesnej eklezjologii prawostawnej (Lawreszuk, 2007), Stosunek Kościoła prawosławnego wobec osób żyjacych w zwiazkach pozamatżeńskich (Ławreszuk, 2014), PAKP i uznanie ukraińskiej autokefalii (Lawreszuk, 2020), Łotocki A., Zasady autokefalii (Łotocki, 1932), Płońska E., Rodzaje i funkcje kar w prawie Kościola prawostawnego w Polsce (Płońska, 2020), Płoński R., Tomosy z 1924 i 1948 roku nadajace status autokefaliczny Polskiemu Autokefalicznemu Kościolowi Prawostawnemu: ich wydźwięk historyczno-kanoniczny (Płoński, 2009), Przed Soborem Wszechprawosławnym, red. Kałużny T., Kijas Z. (Kałużny i Kijas, 2016), Przekop E., Problem wspólnego kodeksu prawa kanonicznego dla Kościołów prawosławnych (Przekop, 1977), Mossakowski W., Ugruntowanie autokefalii prawosławia w Polsce wspótczesnej (Mossakowski, 2012), Szegda M., Sprawa zwołania soboru przez prawostawnych (Szegda, 1962), Tofiluk J., O przygotowaniach do Soboru Wszechprawostawnego (Tofiluk, 1999), Wilkiel K., Historyczne uwarunkowania Soboru Stu Rozdziałów (Wilkiel, 2019), Zachorowski S., Studya z historii prawa kościelnego i polskiego (Zachorowski, 1917), Znosko A., Prawostawne prawo kościelne, cz. I i II (Znosko, 1973, 1975), Zyzykin M., Autokefalia i zasady jej zastosowania (Zyzykin, 1931).

Powyższa bibliografia nie obejmuje opracowań całościowych, analizujących historyczną, teologiczną i praktyczną sferę życia Cerkwi. Publikacje takie również zawierają wartościowe informacje dotyczące prawosławnego prawa kościelnego. W spisie nie uwzględniono również tekstów źródłowych postanowień kanonicznych Soboru Biskupów Polskiego Autokefalicznego Kościoła Prawosławnego lub postanowień Soboru Wszechprawosławnego oraz międzycerkiewnych komisji przedsoborowych. Wykaz publikacji nie obejmuje także cywilnych aktów prawnych obowiązujących w Polsce.

Wskazane publikacje nie stanowią prac przekrojowych, nie podejmują kompleksowej analizy prawosławnego prawa kościelnego. Są to najczęściej wyniki szczegółowych badań związanych z określoną kwestią kanonicznego porządku lub prawnej dyscypliny Cerkwi prawosławnej. Kompleksowy materiał dotyczący prawosławnego prawa kościelnego opiera się w zasadzie na publikacjach dwóch autorów - ks. Aleksego Znosko oraz Edmunda Przekopa. Ich opracowania były opublikowane w latach $70 \mathrm{XX}$ w. Pomijając kwestie prawne ostatnich 50 lat, w tym niezwykle istotne z perspektywy prawosławnego prawa kościelnego komisje przedsoborowe, obrady i postanowienia Soboru Wszechprawosławnego czy prowadzone przez Cerkiew dialogi z Kościołem rzymskokatolickim, czy Kościoła- mi dochalcedońskimi, opracowania wymagają rewizji, a przede wszystkim uaktualnienia. Uwzględniając ponadto problemy eklezjalno-kanoniczne związane $\mathrm{z}$ nadawaniem autokefalii i sporem jurysdykcyjnym na linii Konstantynopol-Moskwa, wydaje się, że nadchodzi czas na ponowne podjęcie badań w dziedzinie prawosławnego prawa kościelnego.

Selekcja materiału źródłowego słownika nie wskazuje bezpośrednio problemu z dostępnością materiałów. Źródła teologiczne stanowią $33 \%$ bazy wyspecjalizowanej, źródła praktyczne $-40,7 \%$, zaś prawne $-26 \%$. Jeśli jednak zauważymy, że baza źródeł prawnych wykorzystała praktycznie wszystkie pozycje polskojęzyczne, to uwidacznia się już problem z dostępnością odpowiedniej liczby źródeł prawosławnego prawa kościelnego w relacji z innymi działami źródeł opisujących Prawosławie.

Praca badawcza nad słownikiem terminologii wykazała brak zarejestrowanych polskich odpowiedników wielu greckich i cerkiewnosłowiańskich terminów z dziedziny prawa kościelnego. Wśród zarejestrowanych polskich terminów wiele jest również takich, które stanowią bezpośrednie zapożyczenie $\mathrm{z}$ języków obcych i nie mają bazy synonimów, np. „diaspora”, „dyptych”, „egzarcha”, „egzarchat”, „ekdyk”, „eklezjarcha”, „ekloga”, „epanagoga”, „epikia”, ,epikeia”, „etnofiletyzm”, „gramota”, „kormcza”, „nomokanon”, ,protekdyk”, „protosynkel” czy „razstryga”. Analiza frekwencyjna źródeł wskazała ponadto, że pomimo prób wprowadzania polskich odpowiedników, wciąż bardziej rozpowszechnione i częściej wykorzystywane są warianty fonetyczne nawiązujące do terminów w języku greckim lub cerkiewnosłowiańskim, co może świadczyć o ich sporadycznym wykorzystaniu. Takim przykładem są terminy ,chorepiskop”, który jest rejestrowany w 3 źródłach (Evdokimov, 1964; Schmemann, 1997; Znosko, 2000), z wariantem „,chorbiskup" wykorzystywanym wyłącznie w opracowaniach ks. A. Znosko. Podobnie traktowany jest termin „pronomia”, wykorzystywany w kontekście prawa cerkiewnego częściej niż pełny synonim ,przywilej”.

\section{Wnioski}

Przeprowadzona analiza ukazuje szereg zadań, które powinny być podjęte w celu pełnej systematyzacji współczesnego prawosławnego prawa kościelnego. Podstawowym problemem jest brak ujednoliconego kodeksu dla Cerkwi powszechnej i ujednoliconego zbioru prawa kościelnego Polskiego Autokefalicznego Kościoła Prawosławnego.

Przepisy powszechnego prawa kościelnego w niewystarczający sposób porządkują kwestie wzajemnych relacji wewnątrz-cerkiewnych, a w szczególności obowiązków i granic prerogatyw lokalnych, autokefalicznych struktur cerkiewnych. Szczególnie współcześnie zagadnienia rozwoju terytorialnego Cerkwi lokalnych, procesy autokefalizacji, nadawania praw autonomii, rozwoju misji czy organizowania życia w diasporach wydają się być 
nieujednolicone. Pomimo opracowania i zatwierdzenia dokumentów Soboru Wszechprawosławnego na Krecie, które odwołują się do części z powyższych kwestii, wciąż możemy mówić nierozwiązanym problemie. Dzieje się tak z powodu braku powszechnej recepcji tychże dokumentów, a przede wszystkim z powodu braku dowodów na stosowanie opracowanych przepisów.

Opierając się na kanonicznej zasadzie Jana Zonarasa, zauważalna jest również konieczność aktualizacji przepisów prawnych poprzez uznanie za nieobowiązujące tych przepisów, które kanonicznie zostały unieważnione późniejszymi kanonami tej samej lub wyższej rangi (Znosko, 1973, s. 71). Zbiory praw Cerkwi prawosławnej mają charakter przyrostowy. Powielane są nawet stare, zmienione lub uchylone kanony. Brak gruntownej aktualizacji praw i ich systematyzacji tematycznej wydaje się najbardziej trudną i czasochłonną pracą badawczą opartą na istniejącym, aczkolwiek rozproszonym materiale źródłowym.

Kolejnym z ukazanych w niniejszym artykule zadaniem jest normatywizacja wykorzystywanej w prawosławnym prawie kościelnym polskiej terminologii. Braki polskojęzycznej literatury przedmiotu, a przede wszystkim ożywienie badań nad prawem kościelnym i kanonicznym wywołane nowymi ustaleniami Soboru Wszechprawosławnego pozwalają przypuszczać, że pojawią się wkrótce próby analiz tej sfery naukowej, co przy braku ujednoliconej terminologii, może prowadzić do nieprecyzyjnych i niespójnych tez i wniosków.

Ostatni wskazany cel powinien być poprzedzony opracowaniem jednolitej struktury terminologicznej uwzględniającej zarówno istniejące $\mathrm{w}$ języku polskim całościowe i fragmentaryczne opracowania, jak też fundamentalne opracowania obcojęzyczne, w tym najnowsze materiały źródłowe i literaturę przedmiotu związaną z przygotowaniami, przebiegiem i ustaleniami Soboru Wszechprawosławnego. Zadanie to może być zrealizowane poprzez opracowanie leksykonu prawosławnego prawa kościelnego. Ze względu na wskazane wyżej problemy związane $\mathrm{z}$ fragmentaryzacją prawa, brakami tematycznymi, niewystarczającą aktualizacją, a przede wszystkim dominacją ujęcia chronologicznego, zasadne wydaje się opracowanie takiego leksykonu w dwóch formach: alfabetycznej i tematycznej.

Wszystkie wskazane wyżej zadania prowokują do podjęcia badań nad współczesnym prawosławnym prawem kościelnym.

\section{Bibliografia}

Agapius a Hieromonk i Nicodemus a Monk (red.) (1957). The Rudder. Przetłumaczone przez D. Cummings. Chicago: The Orthodox Christian Educational Society.

Baron, A. i Pietras, H. (red.) (2006). Dokumenty synodów od 50 do 381 roku. Wydawnictwo WAM (Synody i Kolekcje Praw).

Beneševič, V. N. (1914). Sbornik pamâtnikov po istorii cerkovnogo prava, preimuŝsestvenno russkoj cerkvi do èpohi Petra Velikogo. Petrograd.

Betlejko, J. (2017). „Święty i Wielki Sobór Cerkwi Prawosławnej”, Studia i Dokumenty Ekumeniczne, 33(1).

Blaza, M. (2020). Synodalność (soborowość) W Kościołach wschodnich, Studia Bobolanum, 31, s. 87-111. doi: 10.30439/2020.2.5.

Bóg żywy. Katechizm Kościoła Prawosławnego. (2001). Kraków: Wydawnictwo WAM.

Borkowski, A. (2019). Ekumenizm a realizacja misyjnego posłannictwa Kościoła w kontekście dokumentów Wszechprawosławnego Synodu na Krecie, Elpis, 21, s. 93-97. doi: 10.15290/elpis.2019.21.12.

Charkiewicz, J. (2014). Kanonizacja świętych w prawosławiu. Warszawa: Warszawska Metropolia Prawosławna.

Charkiewicz, J. (2018). Opracowanie listy źródeł „Słownika polskiej terminologii prawosławnej”, Elpis, 20, s. 181-186. doi: 10.15290/elpis.2018.20.19.

Czarnecka, K., Ławreszuk, M. i Przyczyna, W. (2018). „Słownik polskiej terminologii prawosławnej" - struktura artykułu hasłowego, Elpis czasopismo teologiczne Katedry Teologii Prawostawnej Uniwersytetu w Białymstoku, 20, s. 221-230. doi: 10.15290/elpis.2018.20.24.
Dudra, S. (2019). Polski Autokefaliczny Kościół Prawosławny w obszarze polityki wyznaniowej oraz polityki narodowościowej Polski Ludowej i III Rzeczypospolitej. Warszawa: Wydawnictwo Naukowe SCHOLAR.

Evdokimov, P. (1964). Prawostawie. Warszawa.

Hryniewicz, W. (1981). Zasada „ekonomii eklezjalnej” w życiu i teologii prawosławia, Roczniki Teologiczno-Kanoniczne, 28(6), s. 137-152.

J̌ovanović, J. (1844). Načatki cerkovnago prava drevnija pravoslavnija Crkve, s latinskim i srpsko-slovenskim tekstom. Novi Sad. [online] http://digital.bms.rs/ebiblioteka/publications/view/5230, [25.06.2021].

Kałużny, T. (2018). Oikonomia kościelna w teorii i praktyce Prawosławia. Kraków.

Kałużny, T. (2019). Prawosławie i ekumenizm. Kontrowersyjny dokument Soboru na Krecie (2016), Studia Oecumenica, 18, s. 147-160. doi: 10.25167/SOe/18/2018/147-160.

Kałużny, T. i Kijas, Z. (red.) (2016). Przed Soborem Wszechprawosławnym. Kraków: Uniwersytet Papieski Jana Pawła II w Krakowie.

Katechizm Cerkwi prawosławnej. (2001). Hajnówka: Bratczyk.

Kormčaâ napečatana s" originala patriarha Iosifa. (1912). Moskva: Žurnal «Cerkov'».

Kostiuczuk, J. (2013). Ekumenizm w dobie współczesnych wyzwań. W: O tajemnicy zbawienia (159-167). Białystok: Wydawnictwo Uniwersytetu w Białymstoku.

Kostiuczuk, J. (2018). Proces formułowania i doprecyzowania społecznej nauki w oficjalnych dokumentach Rosyjskiego Kościoła Prawosławnego. Elpis czasopismo teologiczne Ka- 
tedry Teologii Prawosławnej Uniwersytetu w Bialymstoku, 20, s. 9-15. doi: 10.15290/elpis.2018.20.01.

Krukowski, J. (2011). Prawo administracyjne w Kościele. Warszawa: Wydawnictwo Uniwersytetu Kardynała Stefana Wyszyńskiego.

Kuźma, A. (2018). Wielki Sobór Kościoła Prawosławnego na Krecie w 2016 r. i jego ustalenia. Elpis czasopismo teologiczne Katedry Teologii Prawosławnej Uniwersytetu w Biabymstoku, 20, s. 165-179. doi: 10.15290/elpis.2018.20.18.

Kuźma, A. (2019). Istota eklezjologii pierwszego tysiąclecia w ujęciu prawosławnym i rzymskokatolickim w świetle dokumentu: „Synodalność i prymat w pierwszym Tysiącleciu: Ku wspólnemu rozumieniu w służbie jedności Kościoła”, Chieti 2016. Elpis, 21, s. 109-120. doi: 10.15290/elpis.2019.21.14.

Ławreszuk, M. (2007). Pojęcie „terenu kanonicznego” we współczesnej eklezjologii prawosławnej”. Elpis, 15-16, s. 209-224.

Ławreszuk, M. (2009). Prawosławie wobec problemu etnofiletyzmu. Elpis, 19-20, s. 73-102.

Ławreszuk, M. (2014). Stosunek Kościoła prawosławnego wobec osób żyjących w związkach pozamałżeńskich. Misc. Hist. - Iurid. doi: 10.15290/mhi.2014.13.02.08.

Ławreszuk, M. (2020). PAKP i uznanie ukraińskiej autokefalii. Wiadomości PAKP, 1, s. 13-17.

Łotocki, A. (1932). Zasady autokefalii. Warszawa.

Mossakowski, W. (2012). Ugruntowanie autokefalii prawosławia w Polsce współczesnej. Studia Iuridica Toruniensia, XI, s. 113-128. [online] https://repozytorium.umk.pl/bitstream/ handle/item/1314/SIT.2012.021\%2CMossakowski.pdf?sequence $=1$, [12.06.2021].

Nikodim episkop Dalmatinskij. (1897). Pravoslavnoe cerkovnoe pravo. Sankt-Peterburg.

Pavlov, A. (1902). Kurs cerkovnogo prava. Svâto-Troickaâ Sergieva Lavra.
Płońska, E. (2020). Rodzaje i funkcje kar w prawie Kościoła prawosławnego w Polsce. Studia Prawnoustrojowe, 47, s. 209-224.

Płoński, R. (2009). Tomosy z 1924 i 1948 roku nadające status autokefaliczny Polskiemu Autokefalicznemu Kościołowi Prawosławnemu: ich wydźwięk historyczno-kanoniczny. Studia Warmińskie, 46, s. 153-171.

Przekop, E. (1977). Problem wspólnego kodeksu prawa kanonicznego dla Kościołów prawosławnych. Studia Płockie, 5, s. 173-183.

Rallis, G. i Potlis, M. Sýntagma tôn theíon kaì iherôn kanónon, 6 vols. Athens.

Schmemann, A. (1997). Eucharystia. Misterium Królestwa. (A. Turczyński, Tłum). Białystok.

Szegda, M. (1962). Sprawa zwołania soboru przez prawosławnych. Prawo Kanoniczne: kwartalnik prawno-historyczny, 5(1-2), s. 211-230.

Tofiluk, J. (1999). O przygotowaniach do Soboru Wszechprawosławnego. Elpis, 1, s. 69-84.

Wilkiel, K. (2019). Historyczne uwarunkowania Soboru Stu Rozdziałów. Elpis, 21, s. 27-33. doi: 10.15290/elpis.2019.21.04.

Yannoulatos, A. (2016). Misja na wzór Chrystusa. Warszawa: Warszawska Metropolia Prawosławna.

Zachorowski, S. (1917). Studya z historyi prawa kościelnego i polskiego. Kraków.

Znosko, A. (1973). Prawostawne prawo kościelne. Część I. Warszawa: Chrześcijańska Akademia Teologiczna.

Znosko, A. (1975). Prawosławne prawo kościelne. Część II (zagadnienia wybrane). Warszawa: Chrześcijańska Akademia Teologiczna.

Znosko, A. (tłum.). (2000). Kanony Kościoła Prawosławnego. 2. wyd. Hajnówka.

Zyzykin, M. (1931). Autokefalia i zasady jej zastosowania. Warszawa. 